\title{
Contribution of environmental pollutants to male infertily: A working model of germ cell apoptosis induced by plasticizers
}

\author{
Raúl Lagos-Cabré and Ricardo D. Moreno' \\ ' Departamento de Fisiología, Facultad de Ciencias Biológicas, Pontificia Universidad Católica de Chile, Santiago Chile.
}

\begin{abstract}
Bisphenol A [2,2-bis(4-hydroxyphenyl)propane] (BPA), 4-nonylphenol (NP) and di(2-ethylhexyl)phthalate (DEHP), and its metabolite mono-2-ethylhexyl phthalate (MEHP) are chemicals found in plastics, which act as endocrine disruptors (EDs) in animals, including human. EDs act like hormones in the endocrine system, and disrupt the physiologic function of endogenous hormones. Most people are exposed to different endocrine disruptors and concern has been raised about their true effect on reproductive organs. In the testis, they seem to preferentially attack developing testis during puberty rather than adult organs. However, the lack of information about the molecular mechanism, and the apparently controversial effect observed in different models has hampered the understanding of their effects on mammalian spermatogenesis. In this review, we critically discuss the available information regarding the effect of BPA, NP and DEHP/ MEHP upon mammalian spermatogenesis, a major target of EDs. Germ cell sloughing, disruption of the blood-testis-barrier and germ cell apoptosis are the most common effects reported in the available literature. We propose a model at the molecular level to explain the effects at the cellular level, mainly focused on germ cell apoptosis.
\end{abstract}

Key words: Testis, spermatogenesis, Bisphenol A, nonylphenol, ADAM17

\section{INTRODUCTION}

Low sperm count (oligospermia), absence of spermatozoa in the semen (azoospermia) and morphological abnormalities are among the primary factors contributing to male infertility (WHO, 2010). The molecular and cellular bases of these pathologies are still not fully understood, but several studies suggest that increased germ cell death (apoptosis) during spermatogenesis may explain decreased sperm production in patients with oligo- and azoospermia. Spermatogenesis is highly influenced by external stimuli, such as drugs, radiation, reproductive and somatic pathologies, seasonal breeding, temperature and environmental pollutants, which increase the constitutive levels of apoptosis in germ cells (Tripathi et al., 2009).

Endocrine disruptors (EDs) involve a great number of molecules capable of inducing estrogenic or antiandrogenic responses in animals, including humans. Phenols and phthalates are among the EDs that can cause male infertility and other pathologies associated with developmental abnormalities. Bisphenol A [2,2-bis(4-hydroxyphenyl)propane] (BPA), 4-nonylphenol (NP) and di(2-ethylhexyl)phthalate (DEHP) and its major metabolite mono(2-ethylhexyl)phthalate (MEHP) are found mainly in polycarbonate plastics, toys, dentist devices, food packaging, blood bags, cosmetics and currency paper (Guenther et al., 2002; ter Veld et al., 2006; EC-SCF, 2007; Liao and Kannan, 2011). Unfortunately they can leach from the lining of plastic packages, cans and baby bottles, and pipe walls. In this way, the human body is exposed to concentrations of $10 \mu \mathrm{g} /$ day of BPA, $7.5 \mu \mathrm{g} /$ day of NP and $30 \mu \mathrm{g} /$ day of DEHP, and they have been detected in human body samples, such as serum, urine, amniotic fluid of pregnant women, breast milk and even in semen (Guenther et al., 2002; Inoue et al., 2002; Calafat et al., 2005; Carlsen et al., 2005; Main et al., 2006; EC-SCF, 2007; Phillips and Tanphaichitr, 2008; Han et al., 2009; Huang et al., 2009; Zhang et al., 2009). Thus, experimental evidence clearly shows that humans are exposed to EDs, which may threaten normal physiology during development and adult life.

Even though these compounds are considered to mimic the effect of estrogen and other steroid hormones, deregulating the control of several hormone-dependent developmental processes (Phillips and Tanphaichitr, 2008; Roy et al., 2009), in vitro assays have shown that the potency of each ED (BPA, NP and DEHP, among others) is much lower than that of estrogen ( 10,000 fold lower than estradiol, E2) (ter Veld et al., 2006). Therefore, it is plausible to propose that these molecules also act through a non-classical estrogenic pathway and probably bind and activate a wide range of proteins, activating different intracellular pathways. This would explain the multiple effects described at the cellular and physiological levels. Particularly relevant are the surviving and dead pathways that are disrupted and/or activated by these molecules, because by inducing germ cell apoptosis they could contribute to lower sperm production in the human testis.

First, we will briefly review the mechanism of apoptosis and the process of spermatogenesis. Then, we will critically discuss the available information linking plasticizers such as BPA, NP and DEHP/MEHP to alteration in normal spermatogenesis. Finally, we propose a molecular pathway in order to explain the deleterious effects of these molecules in spermatogenesis. 


\section{THE MECHANISM OF APOPTOSIS}

Apoptosis is characterized by several hallmarks, such as: internucleosomal DNA fragmentation, caspase activation and externalization of phophatidyl serine (Degterev and Yuan, 2008; Fadeel et al., 2008; Youle and Strasser, 2008). Caspases are serine-proteases that are synthesized as inactive zymogens and become active upon death stimuli. The extrinsic pathway is initiated by activation of death receptors, such as Fas (CD95/Apo-1) or tumor necrosis factor receptor 1 (TNFR1). Trimerization of death receptors in response to ligand biding induces the formation of a multimeric complex termed death inducing signaling complex (DISC), which activates procaspase-8 in mice and capasase-10 in humans (Scaffidi et al., 1998; Scaffidi et al., 1999; Salvesen, 2002; Henkler et al., 2005). Caspase- 8 and/or 10 proteolytically process caspase-3, -6 and -7. Among them, caspase- 3 is the main executioner caspase involved in dismantling the Golgi apparatus, nuclear lamina fragmentation, DNA fragmentation (due in part to proteolysis of a DNAse inhibitor) and the decrease in mitochondrial membrane potential (Sato et al., 2004; Kuribayashi et al., 2006).

The intrinsic pathway of apoptosis could be activated by different stimuli, such as radiation, DNA fragmentation, starvation, oxidative stress and autophagy (Degterev and Yuan, 2008). This pathway is characterized by a decrease in mitochondria membrane potential and release of cytochrome $C$ from the mitochondria, which along with dATP, the cytosolic protein Apaf-1 and procaspase- 9 assemble a complex termed apoptosome. Within this complex, procaspase-9 becomes active and then activates caspase-3, connecting the intrinsic and extrinsic pathways (Shi, 2002; Shi, 2006). Mitochondria membrane stability is preserved by anti-apoptotic protein of the the B-cell lymphoma-2 (BCL-2) family. BCL-2, BCL-x and $B C L-w$ are three anti-apoptotic proteins that interact with and repress the activity of pro-apoptotic proteins. Two general classes of pro-apoptotic family proteins exist: (1) those that share three homology regions (BH1, $\mathrm{BH} 2$ and $\mathrm{BH} 3)$, and that are termed multidomain proteins; and (2) those that share little sequence homology, except for the conserved BH3 domain, also termed "BH3-only" proteins (Chen et al., 2005; Zhai et al., 2008; Ku et al., 2010; Young et al., 2010). Among the "BH3only" group we find Bcl-2 antagonist of cell death (BAD) and p53 upstream modulator (PUMA) (Villunger et al., 2003). It appears that the multidomain pro-apoptotic proteins BAX and BAK are crucial for outer mitochondrial membrane (OMM) permeabilization and the subsequent release of apoptogenic molecules, such as cytochrome-c and DIABLO (also known as SMAC), which leads to caspase-9 activation (Riedl and Shi, 2004; Westphal et al., 2010). Thus, apoptosis is a complex process involving activation of several independent, but convergent pathways in order to induce cell death avoiding an inflammatory response.

\section{MAMMALIAN SPERMATOGENESIS}

The making of mammalian spermatozoa starts with engagement in a differentiation pathway of a diploid cell termed spermatogonium, which establishes itself at the basal lamina of seminiferous tubules (de Rooij and Russell, 2000; Oatley and Brinster, 2008). Through several mitotic divisions, type A spermatogonial stem cells either renew themselves or differentiate into later-stage spermatogonia to eventually initiate meiosis (Oatley and Brinster, 2008). Germ cells in meiosis, spermatocytes, will undergo two successive divisions, without a $S$ phase, and will become haploid round spermatids, which eventually transform into mature spermatozoa (Hermo et al., 2010). Mingled among germ cells are the Sertoli cells, which are the somatic component of seminiferous epithelium that provide mechanical and nutritional support to germ cells (Figure 1). Germ cells in adult rat testes are grouped into 14 cell association or stages (numbered I-XIV) and six in humans (I-VI) (Moreno and Alvarado, 2006). Adjacent Sertoli cells bind to each other through tight junctions (TJs) constituting the blood-testis barrier (BTB) between 10 and 16 days of age in mice, and 20-25 days in rats, providing a protected environment for germ cell development termed the adluminal compartment (Dym and Fawcett, 1970; Sharpe et al., 2003; Yan et al., 2008). The TJs, which are the only known examples of occluding junctions, consist of three classes of integral membrane proteins, namely occludin, claudin and junctional adhesion molecules (Mruk and Cheng, 2004). In this way only spermatogonia and pre-leptotene spermatocytes are attached to the basal lamina and outside from the adluminal compartment (Fig 1).

Numerous studies indicate that Sertoli cells are involved in the progression of spermatogenesis through a variety of paracrine signals regulating gene expression and metabolism of germ cells (Skinner, 2005). Sertoli cells regulate survival of germ cells via paracrine secretion of trophic factors such as insulin growth factor (IGF), nerve growth factor (NGF), growth factor derived from glia (GDNF) and stem cell factor (SCF). Moreover, it has been shown that apoptosis of germ cells is somehow controlled by hormonal levels including testosterone, estrogen and FSH (Shetty et al., 1996; Yan et al., 2000b; Tesarik et al., 2002). Testosterone is essential for meiosis and subsequent differentiation of spermatids (De Gendt et al., 2004). Testosterone exerts its action through the Sertoli cell, which expresses the androgen receptor, and stimulates the synthesis of various proteins and trophic factors in specific periods of spermatogenesis (Wang et al., 2009). Therefore, germ cell development is a complex differentiation process controlled by juxta/paracine, and endocrine interactions.

\section{APOPTOSIS DURING MAMMALIAN SPERMATOGENESIS}

Sperm production relies on physiological and environmental factors, which may attenuate or even totally suppress testicular function. Germ cell apoptosis has been shown to play an important role in controlling sperm output in many species and has been linked to infertility in humans (Feng et al., 1999; Weikert et al., 2004; Ji et al., 2009). Germ cells undergoing meiosis (spermatocytes) are highly sensitive to heat shock, ionizing radiation, growth factor deprivation, and chemotherapeutic agents (Russell, 2004; Bieber et al., 2006; Lizama et al., 2009; Silva et al., 2011). Many studies have shown the relevance of apoptosis in regulating spermatozoa output and eliminating damaged germ cells (Knudson et al., 1995; Beumer et al., 1998; Yin et al., 1998; Allemand et al., 1999; Feng et al., 1999; Honarpour et al., 2000; Yan et al., 2000a; Russell et al., 2002; Moreno et al., 2006). To this end, it has been reported that massive germ cell death occurs under physiological conditions (constitutive apoptosis) during the first round of spermatogenesis (Oakberg, 1956; Rodriguez et al., 1997; Moreno et al., 2006). Different experimental 


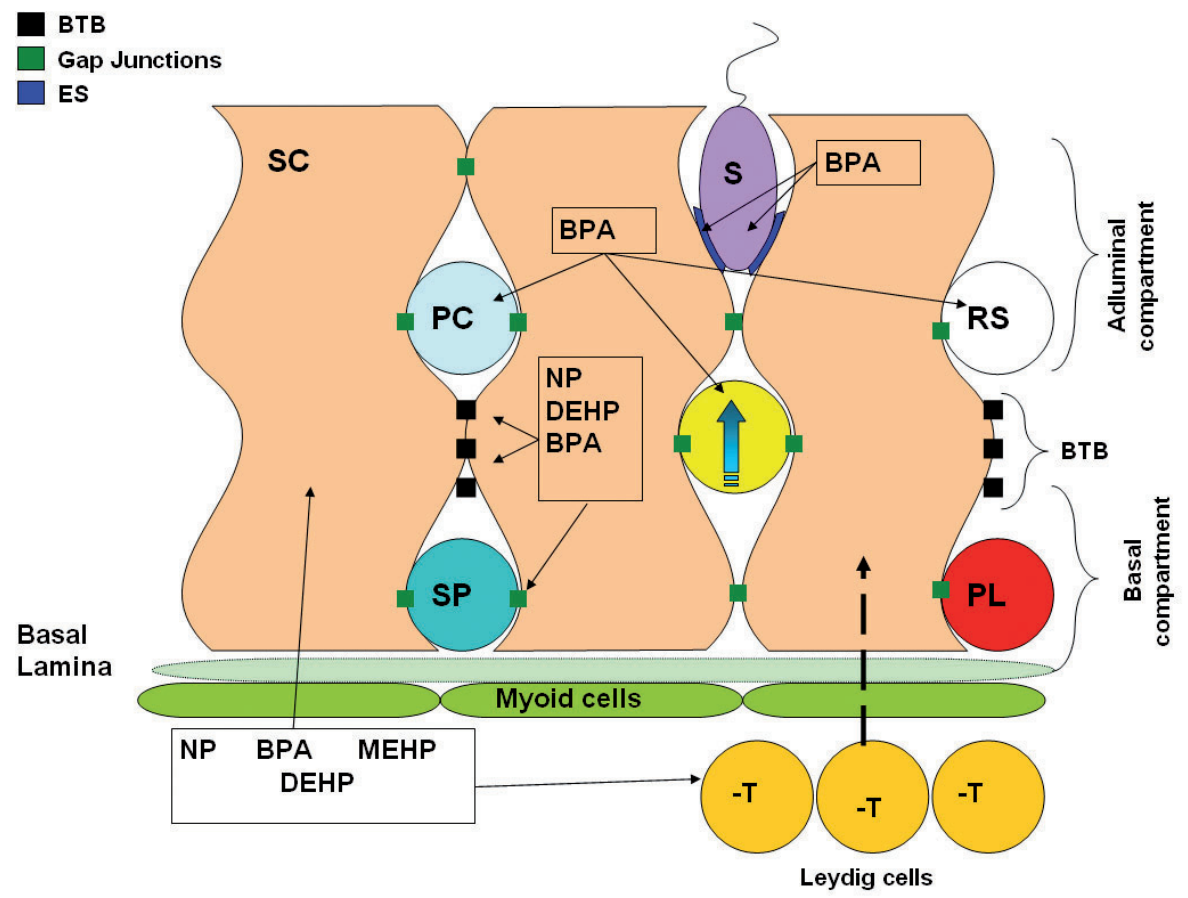

Figure 1: Major targets of BPA, NP and MEHP in a mammalian testis. Bisphenol A (BPA), 4-nonylphenol (NP) and di(2-ethylhexyl) phthalate (DEHP) disrupt spermatogenesis at different levels. They lower intratesticular and plasma testosterone (T) by affecting Leydig cells, resulting in decreased spermatogenesis. In addition, in vitro and in vivo studies show that Sertoli cells (SC) are primary targets of these compounds, affecting their metabolism, protein expression and morphology. BPA induces spermatogonium (SP), pachytene spermatocyte (PC) and preleptotene spermatocyte (PIC) apoptosis by affecting SC. The blood-testis barrier (BTB), which separates the adluminal compartment from the basal compartment within seminiferous tubules, ectoplasmic specializations (ES), which maintain attached elongated spermatids (S) to SC, and gap junctions (GJ) are disrupted by EDs, producing sloughing and apoptosis of germ cells.

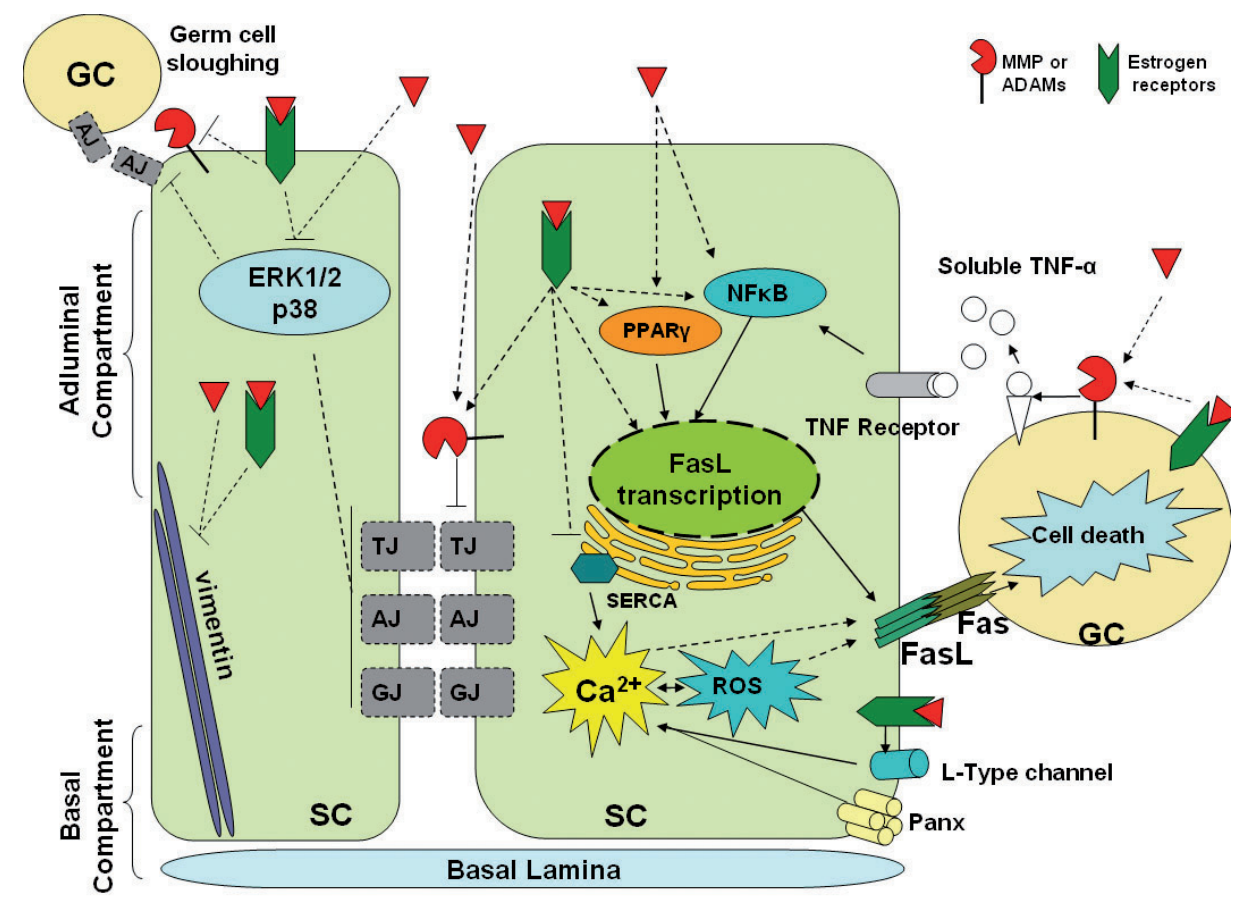

Figure 2: Model of the effects of EDs on Sertoli-germ cell interaction and germ cell apoptosis and sloughing. Depiction of a model of para/juxtacrine signaling events between germ cells (GC) and Sertoli cells during apoptosis induced by endocrine disruptors. Dotted lines indicate an unknown mechanism.

Triangles represent EDs molecules. 
approaches have pointed out that spermatocytes are the main cell type undergoing apoptosis, with a smaller fraction of spermatogonia also undergoing the process (Jahnukainen et al., 2004; Moreno et al., 2006).

During spermatogenesis, about $75 \%$ of germ cell die in every round of spermatogenesis (Huckins, 1978). One possibility for this massive germ cell death is that the Sertoli cells provide an appropriate environment only to a certain amount of germ cells, so that apoptosis would serve as a mechanism to remove excess of germ cells that cannot be supported by Sertoli cells. Another hypothesis is that apoptosis is used to eliminate germ cells that do not pass the control points of the cell cycle. In several mammalian species, apoptosis occurs simultaneously with the mitotic divisions of the spermatogonia and with the beginning of meiosis of spermatocytes (Blanco-Rodriguez, 2002; Blanco-Rodriguez et al., 2003). This suggests that the checkpoints could be helping to correct the number of germ cells in relation to the number of Sertoli cells, acting specifically on cells with problems of chromosomal rearrangements during meiosis or damaged cells unable to repair the breaks in their DNA (Salazar et al., 2003; Salazar et al., 2005).

The importance of apoptosis in spermatogenesis is evident when pro-apoptotic genes are deleted (BAX, Bim or Bik) or anti-apoptotic genes are overexpressed (such as BCL-2). Both conditions are associated with infertility due to the arrest of spermatogenesis at the onset of meiosis (Knudson et al., 1995; Feng et al., 1999; Yamamoto et al., 2001; Russell et al., 2002; Yan et al., 2003; Coultas et al., 2005). Furthermore, inhibiting the engulfment of apoptotic bodies by Sertoli cells decreases sperm production and mice become sub-fertile (Maeda et al., 2002; Elliott et al., 2010). Results from our laboratory indicate an increase in the levels of the Fas receptor, the transcription factor p53 and the activation of caspases 8, 9, 32 and 6 in apoptotic germ cells (Lizama et al., 2007; Codelia et al., 2008). Interestingly, anti-cancer drugs, such as etoposide, which promotes DNA breaks by inhibiting topoisomerase II, induce apoptosis in spermatocytes (Ortiz et al., 2009; Codelia et al., 2010; Lizama et al., 2011; Lizama et al., 2012) by activating p73 and caspases. Thus, it seems that some elements of the mechanism involving constitutive (physiological) pathways are shared with externally induced apoptosis.

\section{ADVERSE EFFECTS OF ENDOCRINE DISRUPTORS ON HUMAN FERTILITY}

Clinical studies suggest that EDs could affect reproductive tract development because DEHP exposure during pregnancy correlates with low birth weight (Zhang et al., 2009) and a decrease in the anogenital distance (AGD) in females. In males, a reduced AGD accompanied by incomplete testicular descent has been observed in boys prenatally exposed to phthalates (Swan et al., 2005). Additionally, several abnormalities regarding secondary sexual characteristics have been observed in boys and girls when EDs are present, for example, girls exposed in utero to high doses of polybrominated biphenyls (PBB), >7 parts per billion (ppb) show an early menarche (at least one year earlier) than those who were not exposed to this ED (Blanck et al., 2000), while boys exposed in utero to pesticides show a significant decrease in penis length at the age of 3 months, along with a low testicular volume and decreased T levels (Andersen et al.,
2008). Cultured human fetal testes treated with MEHP show an increase in apoptosis of germ cells and reduced expression of anti-Müllerian hormone mRNA, which may be linked to the feminization effect exerted in utero (Lambrot et al., 2009). In this regard, it is worth mentioning that millions of women in the USA between the 1950s and 1970s were treated with diethilbestrol (DES), an artificial estrogen that was prescribed to pregnant women to avoid miscarriages. $31.5 \%$ of the male children of these women showed abnormalities in their reproductive tracts, including epididymal cyst and hyposplastic testes in adulthood, compared to only $7.8 \%$ of males who presented these abnormalities when their mothers did not take DES (Bibbo et al., 1977; Gill et al., 1979; Jensen et al., 1995; Toppari et al., 1996). These males also showed decreased ejaculated volume and sperm abnormalities (Bibbo et al., 1977), suggesting that in utero exposure to estrogen is a major factor in male genital abnormalities observed in adulthood. The transgenerational and long-term negative effects on male testes were evidenced by the grandsons of women who received DES showing a high risk for hypospadias (Klip et al., 2002; Brouwers et al., 2006).

During a breastfeeding study, several phthalate monoesters were transferred to newborns from contaminated breast milk and these babies show low free $\mathrm{T}$ levels along with an increase in the luteinizing hormone $(\mathrm{LH}) / \mathrm{T}$ ratio, indicating a possible adverse effect on Leydig cells or the gonadal-pituitary axis (Main et al., 2006). Similar effects have been observed in infertile men with high DEHP levels in semen, who also show an increase in serum estradiol (E2) and prolactin (PRL) (Li et al., 2011b). In fertile men, no significant associations were found among any semen parameters and urinary BPA concentrations (Mendiola et al., 2010). However, a significant inverse association was detected among urinary BPA concentrations free androgen index (FAI) levels and the FAI/ $\mathrm{LH}$ ratio, as well as a significant positive association between BPA and sex hormone-binding globulin (SHBG). These results suggest that low BPA concentrations may be linked to subtle variations in sex hormones in fertile men.

The output and quality of sperm are useful tools to measure the effect of exogenous compounds on spermatogenesis. A high correlation has been observed between urine BPA levels and semen quality in Chinese men (including motility, viability, sperm count and sperm concentration), which also correlated with the educational level and longer employment history; men with better education and a long history of employment had lower levels of BPA since they were not in contact with EDs, unlike men who worked in factories ( $\mathrm{Li}$ et al., 2011a). Urine BPA levels could also be associated with sperm abnormalities and sperm DNA fragmentation (suggesting apoptosis) in men from an infertility clinic (Meeker et al., 2010). However, direct application of BPA to human sperm samples does not produce any negative effects (Bennetts et al., 2008), suggesting that the observed negative effects could be induced during spermatogenesis and/or epididymal transit and not through a direct effect on spermatozoa. Regarding DEHP effects, it has been shown that infertile men in India who present DEHP levels of up to $0.77 \pm 1.2 \mu \mathrm{g} / \mathrm{mL}$ in semen have the following sperm abnormalities: reduced sperm count and motility, depolarized mitochondrial membrane, higher levels of reactive oxygen species (ROS) in semen and higher lipid peroxidation levels that correlate to the DEHP levels observed in these patients 
(Pant et al., 2008). Similar effects have been observed in Chinese men where high urine BPA levels correlate with low sperm count, motility and concentration (Li et al., 2011a).

A recent study demonstrated that DEHP-contaminated air was associated with an increase in sperm DNA fragmentation and a decrease in sperm motility in polyvinyl chloride (PVC) factory workers (Huang et al., 2011). As in the case of DEHPexposed workers, air BPA-exposed workers also show reduced sexual desire, accompanied by erectile dysfunction and ejaculation difficulties (Li et al., 2010). Diet and residential area (urban or rural) could be important factors related to the negative effects of EDs, since consumption of certain foods from contaminated areas could increase the levels of EDs in semen. In this regard, infertile men who live in urban areas and have a fish-based diet (probably from contaminated waters) have higher levels of polychlorinated biphenyls and phthalate esters than those of men who live in urban areas, but with a diet that does not include fish. These men showed reduced levels of progressive sperm motility, lower ejaculated volume and sperm vitality compared to fertile men (Rozati et al., 2002). It has been determined that high levels of organochlorine pesticides could be related to sperm abnormalities in greenhouse workers (Abell et al., 2000). These compounds have also been detected in young men (Carreno et al., 2007) who live near agricultural areas in southern Spain, suggesting possible risk factors of living and ingesting food from or near contaminated areas. The paucity of studies regarding the role of EDs in human reproductive functions limits the extent to which conclusions can be made. Despite that, the available data strongly suggest an adverse effect of BPA, NP and DEHP on sex hormone levels and semen parameters.

\section{EDS AFFECT SPERMATOGENESIS AND INDUCE GERM CELL APOPTOSIS IN ANIMAL MODELS}

A reduction in Leydig cell numbers and $\mathrm{T}$ plasma levels have been observed in pubertal mice orally receiving 160 to $960 \mathrm{mg} / \mathrm{kg}$ of BPA for thirteen days (Li et al., 2009). However, treatment of adult mice and rats (Toyama et al., 2004) with 20 to $200 \mu \mathrm{g} / \mathrm{kg}$ of BPA for six days produced abnormalities in ectoplasmic specializations (ES) in elonged spermatids, without major changes in Sertoli or Leydig cells. ES are testisspecific adherens junctions between elonged spermatids and Sertoli Cells, and their assembly and stability rely on T levels (Wong et al., 2005; Ruwanpura et al., 2010). E2 administration has also been shown to decrease ES stability by reducing $\mathrm{T}$ levels (Wong et al., 2005); therefore, it is possible that application of BPA mimics the effect of E2, thus affecting $\mathrm{T}$ levels and disrupting ES between elongated spermatids and Sertoli cells.

BPA increases Fas and FasL levels in germ and Sertoli cells, respectively, accompanied by activation of caspase- 3 in germ and Leydig cells when administered by gavage to pubertal mice ( $\mathrm{Li}$ et al., 2009). Administration of 1.2 to $10 \mu \mathrm{g} /$ day of BPA for five days to neonatal male rats lowers sperm count and motility in adulthood, accompanied by a low mating rate and sloughing of germ cells, hence demonstrating the long-term effects of these compounds and suggesting that EDs accumulate in the body and/or metabolic pathways are permanently disrupted (Salian et al., 2009). Male mice whose mothers received an implant containing varying BPA concentrations from before mating until four weeks postnatal (weaning) show increased $\mathrm{T}$ plasma levels with low doses of BPA $(1.2 \mu \mathrm{g} /$ day $)$, but decreased levels with higher doses of BPA $(60 \mu \mathrm{g} /$ day), along with a sloughing of germ cells and a reduction of seminiferous tubules with elongated spermatids (Okada and Kai, 2008). Similarly, prepubertal mice administered $50 \mu \mathrm{g} / \mathrm{mL}$ of BPA in drinking water have been shown to have decreased $\mathrm{T}$ levels and multinucleated germ cells (Takao et al., 2003).

DEHP and its active metabolite MEHP might be one of the most environmentally abundant phthalates and have been shown to deplete gonocytes (future germ cells) in fetal rat testes and decrease $T$ levels (Chauvigne et al., 2009). These effects have also been observed in human fetal testes, but without a T level decrease (Lambrot et al., 2009). Both studies show that Sertoli cells are unaffected and that Leydig cells remain active, but only in human fetal testes. When administered during the gestational period, DEHP (10mg/ $\mathrm{kg}$ ) produces several negative effects on Leydig cells, such as a decrease in volume and number, and an increase in T plasma levels. On the contrary, higher doses of DEHP (750mg/ $\mathrm{kg}$ or $1 \mathrm{~g} / \mathrm{Kg}$ ) decrease $\mathrm{T}$ plasma levels (Lin et al., 2008) and increases germ cell apoptosis compared to wild type mice (Lin et al., 2010). A single dose of $2 \mathrm{~g} / \mathrm{kg}$ of MEHP by gavage to prepubertal rats has been observed to disrupt vimentin filaments in Sertoli cells and activates apoptosis only in germ cells, as evidenced only by TUNEL and DNA fragmentation assays These effects were observed as early as 12 hours after MEHP administration (Richburg and Boekelheide, 1996). Prepubertal mice treated with $1 \mathrm{~g} / \mathrm{kg}$ of MEHP show an upregulation of FasL and TNF- $\alpha 1.5$ hours after exposure through activation of NFkB (Yao et al., 2007). The same study showed an increase in FasL (mRNA and protein levels) in primary Sertoli cell cultures and ASD17D cells (Sertoli cell line), which is akin to the effect of BPA on mice testes ( $\mathrm{Li}$ et al., 2009). These results suggest that FasL increase in Sertoli cells could be a common pathway and a major player in BPA- and DEHP/MEHP-induced germ cell apoptosis (Figs $1,2)$. Studies in gld mice harboring an inactivating mutation in FasL have shown decreased apoptosis of germ cells after MEHP exposure, demonstrating the role of this protein in EDs-induced apoptosis (Richburg et al., 2000). On the other hand, mice lacking FasL (FasL ${ }^{-/-}$) show an increase in basal levels of germ cell apoptosis, and when exposed to $1 \mathrm{~g} / \mathrm{kg}$ of MEHP, they show a dramatic decrease in the high basal germ cell apoptosis (Lin et al., 2010). This could be because of a significant increase in c-FILP levels, and endogenous caspase-8 inhibitor, after MEHP treatment only in FasL ${ }^{-/-}$ice. Even though increases in c-FLIP levels in $\mathrm{FasL}^{-/-}$mice after MEHP may account for the observed decreases in germ cell apoptosis, the mechanism underlying c-FLIP protein levels regulation in these mice after MEHP exposure is not readily apparent (Lin et al., 2010).

Oral administration of NP (1, 10 and $100 \mu \mathrm{g} / \mathrm{kg} /$ day $)$ to male rats decreased epididymis and testis weight, as well as epididymal sperm count. Interestingly, NP-treated male rats show greater ROS production and decreased antioxidant enzyme levels compared to controls (Chitra et al., 2002). Administration of NP $(125,250$ and $300 \mathrm{mg} / \mathrm{kg} /$ day $)$ for sixty days to 20-day old rats elicits Fas and FasL mRNA upregulation in testes and increases TUNEL-positive cells compared to controls (Han et al., 2004), which is in agreement 
with the effects produced by BPA and DEHP/MEHP described above. Activation of the extrinsic pathway seems to have a major role in germ cell apoptosis induced by BPA, DEHP and $\mathrm{NP}$, which is similar to the physiological conditions (Moreno et al., 2006).

During spermatogenesis, germ and Sertoli cells are in close physical and functional contact through gap junctions (GJ), tight junctions (TJ) and adheren junctions (AJ). GJs mediate communication by forming intercellular pores by the docking of two hemichannels of adjacent cells. These hemichannels are composed of connexins (Cx), which are a protein family composed of about 20 members of transmembrane proteins (Decrock et al., 2009). TJs and AJs, along with intermediate filament-based desmosome junctions, are located near the basement membrane of the seminiferous tubule forming the blood-testis barrier (BTB), which allows the existence of a basal and adluminal compartment (Fig 1) to generate a specific microenvironment for germ cell development (Cheng and Mruk, 2002; Lee and Cheng, 2004). In vivo and in vitro studies show that TJs, AJs and GJs are targets of EDs that affect SertoliSertoli and Sertoli-germ cell interactions (Fig 1). In addition, disruption of vimentin filaments by MEHP promotes germ cell detachment due to Sertoli cells shrinking. NP administration to pregnant rats during gestation, lactancy and 10 weeks after weaning (corresponding to a complete lifespan exposed to NP) have been shown to decrease epithelial thickness, probably due to Sertoli cells shrinking and an increase in germ cell apoptosis (de Jager et al., 1999; McClusky et al., 2007). ). In summary, all the evidence indicates that directly, or indirectly through the Sertoli cells, EDs sever the interaction between Sertoli and germ cells and thereby provoke detachment (sloughing) of germ cells.

\section{A MOLECULAR MODEL OF EDS IN MAMMALIAN TESTES}

The effect observed by EDs in testes may be mediated primarily by nuclear estrogen receptors (ER) alpha and beta (ER $\alpha$ and ER $\beta$ ), which are expressed by Sertoli and germ cells ( $\mathrm{O}^{\prime}$ Donnell et al., 2001). ERs are activated by a large number of ligands (hormones, environmental pollutants and phytoestrogens, among others). In fact, BPA induces changes in the levels of ER $\alpha$ and ER $\beta$ in adult mice testes (Takao et al., 2003) and affects the recruitment of their coactivator (Routledge et al., 2000). These receptors can generate two possible responses: a genomic response, which leads to gene expression, and a non-genomic response, a faster response involving kinase phosphorylation and ion channel regulation (Marino et al., 2006; Fu and Simoncini, 2008). This non-classical membrane estrogen receptor (ncmER), which is a G-protein coupled receptor, produces a fast activation of voltage-gated channels, thus raising the intracellular $\mathrm{Ca}^{2+}\left(\mathrm{iCa}^{2+}\right)$ concentration in the target cell (Carmeci et al., 1997; Marino et al., 2006).

It has been described that Sertoli cells in vitro exposed to a variety of EDs show an increase in $\mathrm{iCa}^{2+}$, which could be due to an external influx or a depletion in intracellular stores, by inhibiting the SERCA pump at the endoplasmic reticulum (Hughes et al., 2000; Gong et al., 2008) (Fig 2). However, we cannot exclude the possibility of a genomic participation of ERs in germ cell apoptosis and sloughing, since there is an increase in FasL expression by a genomic pathway in TM4 (a Sertoli-like cell line) cells treated with E2 (Catalano et al., 2007). In addition to an increase in $\mathrm{iCa}^{2+}$ in Sertoli cells exposed to
$\mathrm{NP}$, increased ROS production has also been observed (Gong and Han, 2006), demonstrating another mode of action of these compounds. It is possible that elevated ROS production is associated with mitochondrial and/or endoplasmic reticulum stress. This hypothesis is supported by the findings that in primary Sertoli cell cultures, NP increases ROS levels and lipid peroxidation while decreasing mitochondrial membrane potential (Gong and Han, 2006), which are all characteristics of oxidative stress. In this regard, it has been shown that stress signals are related to an increase in ROS production, along with an activation of the p38MAPK pathway (Liu and Chang, 2009) that in turn upregulates the Fas/FasL system. However, EDs promote inactivation of p38MAPK and ERK1/2 in isolated Sertoli cells and TM4 cells (Aravindakshan and Cyr, 2005; Bhattacharya et al., 2005), which has been related to the downregulation of $\mathrm{TJ}, \mathrm{AJ}$ and GJ proteins and in this way induces sloughing and apoptosis of germ cells, showing that the mechanisms of ED affects spermatogenesis are still a subject of controversy.

Several lines of evidence shown here suggest the participation of the Fas-FasL system in the apoptosis of germ cells elicited by EDs. It has been demonstrated in MCF7 cells that FasL expression depends on peroxisome proliferatoractivated receptor- $\gamma$ (PPAR $\gamma$ ) through the binding of the SP1 transcription factor (Bonofiglio et al., 2009), both of which are expressed in mammalian testes (Fig 2). However, there are no data available supporting this proposal.

It has recently been shown that matrix metalloproteinase 2 (MMP2) is involved in the disruption of junction complexes between Sertoli-Sertoli and Sertoli-germ cells (Yao et al., 2010). They also observed an early increase in ADAM10 and ADAM17 protein levels, which can participate in the MEHP response. Following treatment with a single dose of MEHP, the levels of the inhibitor of MMP2, TIMP2, decrease significantly and as a consequence, the MMP2 activity increases (Yao et al., 2009). ADAM10 and ADAM17 belong to a family of extracellular proteases that are involved in the release of many protein ectodomains from the cell surface, including TNF- $\alpha$, FasL, Notch, APP and TrkA, thus indicating a strong participation in autocrine, paracrine and juxta/paracrine signaling (Schlondorff and Blobel, 1999; White, 2003). They are widely distributed in the male reproductive tract, however the biological function of many of these proteases is still unknown (Moreno et al., 2011). It is possible that ADAM17 may participate in TNF- $\alpha$ shedding from germ cell plasma membrane and exert paracrine signaling on Sertoli cells. In addition, ADAM17 can also shed the extracellular domain of JAM-A (Koenen et al., 2009), a well known protein of TJs (see above), hence destabilizing the BTB and leading to germ cell sloughing (Fig. 2).

Our model puts forward ADAM metalloproteases as novel elements in germ cell apoptosis following ED treatment. Interestingly, we have recently shown that the ADAM17mediated shedding of the c-kit extracellular domain is involved in germ cell apoptosis, suggesting that this could be a mechanism common to physiological and ED-induced germ cell apoptosis (Lizama et al., 2010).

\section{ACKNOWLEDGMENT}

Part of this work was financed by FONDECYT (1110778) to RDM and AT-24100089 to RLC. 


\section{REFERENCES}

ABELL A, ERNST E, BONDE JP (2000) Semen quality and sexual hormones in greenhouse workers. Scand J Work Environ Health 26: 492-500.

ALLEMAND I, ANGLO A, JEANTET AY, CERUTTI I, MAY E (1999) Testicular wild-type p53 expression in transgenic mice induces spermiogenesis alterations ranging from differentiation defects to apoptosis. Oncogene 18: 6521-6530.

ANDERSEN HR, SCHMIDT IM, GRANDJEAN P, JENSEN TK, BUDTZJORGENSEN E, KJAERSTAD MB, BAELUM J, NIELSEN JB, SKAKKEBAEK NE, MAIN KM (2008) Impaired reproductive development in sons of women occupationally exposed to pesticides during pregnancy. Environ Health Perspect 116: 566-572.

ARAVINDAKSHAN J, CYR DG (2005) Nonylphenol alters connexin 43 levels and connexin 43 phosphorylation via an inhibition of the p38mitogen-activated protein kinase pathway. Biol Reprod 72: 1232-1240.

BENNETTS LE, DE IULIIS GN, NIXON B, KIME M, ZELSKI K, MCVICAR CM, LEWIS SE, AITKEN RJ (2008) Impact of estrogenic compounds on DNA integrity in human spermatozoa: evidence for cross-linking and redox cycling activities. Mutat Res 641: 1-11.

BEUMER TL, ROEPERS-GAJADIEN HL, GADEMAN IS, VAN BUUL PP, GIL-GOMEZ G, RUTGERS DH, DE ROOIJ DG (1998) The role of the tumor suppressor p53 in spermatogenesis. Cell Death Differ 5: 669-677.

BHATTACHARYA N, DUFOUR JM, VO MN, OKITA J, OKITA R, KIM KH (2005) Differential effects of phthalates on the testis and the liver. Biol Reprod 72: 745-754.

BIBBO M, GILL WB, AZIZI F, BLOUGH R, FANG VS, ROSENFIELD RL, SCHUMACHER GF, SLEEPER K, SONEK MG, WIED GL (1977) Followup study of male and female offspring of DES-exposed mothers. Obstet Gynecol 49: 1-8.

BIEBER AM, MARCON L, HALES BF, ROBAIRE B (2006) Effects of chemotherapeutic agents for testicular cancer on the male rat reproductive system, spermatozoa, and fertility. J Androl 27: 189-200.

BLANCK HM, MARCUS M, TOLBERT PE, RUBIN C, HENDERSON AK, HERTZBERG VS, ZHANG RH, CAMERON L (2000) Age at menarche and tanner stage in girls exposed in utero and postnatally to polybrominated biphenyl. Epidemiology 11: 641-647.

BLANCO-RODRIGUEZ J (2002) Deoxyribonucleic acid replication and germ cell apoptosis during spermatogenesis in the rabbit. J Androl 23: 182187.

BLANCO-RODRIGUEZ J, MARTINEZ-GARCIA C, PORRAS A (2003) Correlation between DNA synthesis in the second, third and fourth generations of spermatogonia and the occurrence of apoptosis in both spermatogonia and spermatocytes. Reproduction 126: 661-668.

BONOFIGLIO D, GABRIELE S, AQUILA S, QI H, BELMONTE M, CATALANO S, ANDO S (2009) Peroxisome proliferator-activated receptor gamma activates fas ligand gene promoter inducing apoptosis in human breast cancer cells. Breast Cancer Res Treat 113: 423-434.

BROUWERS MM, FEITZ WF, ROELOFS LA, KIEMENEY LA, DE GIER RP, ROELEVELD N (2006) Hypospadias: a transgenerational effect of diethylstilbestrol? Hum Reprod 21: 666-669.

CALAFAT AM, KUKLENYIK Z, REIDY JA, CAUDILL SP, EKONG I, NEEDHAM LL (2005) Urinary concentrations of bisphenol A and 4-nonylphenol in a human reference population. Environ Health Perspect 113: 391-395.

CARLSEN E, SWAN SH, PETERSEN JH, SKAKKEBAEK NE (2005) Longitudinal changes in semen parameters in young Danish men from the Copenhagen area. Hum Reprod 20: 942-949.

CARMECI C, THOMPSON DA, RING HZ, FRANCKE U, WEIGEL RJ (1997) Identification of a gene (GPR30) with homology to the G-proteincoupled receptor superfamily associated with estrogen receptor expression in breast cancer. Genomics 45: 607-617.

CARRENO I, RIVAS A, GRANADA A, JOSE LOPEZ-ESPINOSA M, MARISCAL M, OLEA N, OLEA-SERRANO F (2007) Exposure of young men to organochlorine pesticides in Southern Spain. Environ Res 103: 55-61.

CATALANO S, RIZZA P, GU G, BARONE I, GIORDANO C, MARSICO S, CASABURI I, MIDDEA E, LANZINO M, PELLEGRINO M, ANDO $S$ (2007) Fas ligand expression in TM4 Sertoli cells is enhanced by estradiol „in situ“ production. J Cell Physiol 211: 448-456.

CODELIA VA, CISTERNA M, ALVAREZ AR, MORENO RD (2010) p73 participates in male germ cells apoptosis induced by etoposide. Mol Hum Reprod 16: 734-742.
CODELIA VA, CISTERNAS P, MORENO RD (2008) Relevance of caspase activity during apoptosis in pubertal rat spermatogenesis. Mol Reprod Dev 75: 881-889.

COULTAS L, BOUILLET P, LOVELAND KL, MEACHEM S, PERLMAN H, ADAMS JM, STRASSER A (2005) Concomitant loss of proapoptotic BH3-only Bcl-2 antagonists Bik and Bim arrests spermatogenesis. Embo J 24: 3963-3973.

CHAUVIGNE F, MENUET A, LESNE L, CHAGNON MC, CHEVRIER C, REGNIER JF, ANGERER J, JEGOU B (2009) Time- and dose-related effects of di-(2-ethylhexyl) phthalate and its main metabolites on the function of the rat fetal testis in vitro. Environ Health Perspect 117: 515521.

CHEN L, WILLIS SN, WEI A, SMITH BJ, FLETCHER JI, HINDS MG, COLMAN PM, DAY CL, ADAMS JM, HUANG DC (2005) Differential targeting of prosurvival $\mathrm{Bcl}-2$ proteins by their BH3-only ligands allows complementary apoptotic function. Mol Cell 17: 393-403.

CHENG CY, MRUK DD (2002) Cell junction dynamics in the testis: Sertoligerm cell interactions and male contraceptive development. Physiol Rev 82: 825-874.

CHITRA KC, LATCHOUMYCANDANE C, MATHUR PP (2002) Effect of nonylphenol on the antioxidant system in epididymal sperm of rats. Arch Toxicol 76: 545-551.

DE GENDT K, SWINNEN JV, SAUNDERS PT, SCHOONJANS L, DEWERCHIN M, DEVOS A, TAN K, ATANASSOVA N, CLAESSENS F, LECUREUIL C, HEYNS W, CARMELIET P, GUILLOU F, SHARPE RM, VERHOEVEN G (2004) A Sertoli cell-selective knockout of the androgen receptor causes spermatogenic arrest in meiosis. Proc Natl Acad Sci U S A 101: 1327-1332.

DE JAGER C, BORNMAN MS, OOSTHUIZEN JM (1999) The effect of p-nonylphenol on the fertility potential of male rats after gestational, lactational and direct exposure. Andrologia 31: 107-113.

DE ROOIJ DG, RUSSELL LD (2000) All you wanted to know about spermatogonia but were afraid to ask. J Androl 21: 776-798.

DECROCK E, VINKEN M, DE VUYST E, KRYSKO DV, D'HERDE K, VANHAECKE $T$, VANDENABEELE P, ROGIERS V, LEYBAERT L (2009) Connexin-related signaling in cell death: to live or let die? Cell Death Differ 16: 524-536.

DEGTEREV A, YUAN J (2008) Expansion and evolution of cell death programmes. Nat Rev Mol Cell Biol 9: 378-390.

DYM M, FAWCETT DW (1970) The blood-testis barrier in the rat and the physiological compartmentation of the seminiferous epithelium. Biol Reprod 3: 308-326.

EC-SCF (2007) Opinion of the Scientific Panel on Food Additives, Flavourings, Processing Aids and Materials in Contact with Food on a request from the Commission related to 2,2-BIS(4-HYDROXYPHENYL) PROPANE (Bisphenol A). EFSA J: DOI:10.2903/j.efsa.2007.2428.

ELLIOTT MR, ZHENG S, PARK D, WOODSON RI, REARDON MA, JUNCADELLA IJ, KINCHEN JM, ZHANG J, LYSIAK JJ, RAVICHANDRAN KS (2010) Unexpected requirement for ELMO1 in clearance of apoptotic germ cells in vivo. Nature 467: 333-337.

FADEEL B, OTTOSSON A, PERVAIZ S (2008) Big wheel keeps on turning: apoptosome regulation and its role in chemoresistance. Cell Death Differ 15: 443-452.

FENG HL, SANDLOW JI, SPARKS AE, SANDRA A, ZHENG LJ (1999) Decreased expression of the c-kit receptor is associated with increased apoptosis in subfertile human testes. Fertil Steril 71: 85-89.

FU XD, SIMONCINI T (2008) Extra-nuclear signaling of estrogen receptors. IUBMB Life 60: 502-510.

GILL WB, SCHUMACHER GF, BIBBO M, STRAUS FH, 2ND, SCHOENBERG HW (1979) Association of diethylstilbestrol exposure in utero with cryptorchidism, testicular hypoplasia and semen abnormalities. J Urol 122: 36-39.

GONG Y, HAN XD (2006) Nonylphenol-induced oxidative stress and cytotoxicity in testicular Sertoli cells. Reprod Toxicol 22: 623-630.

GONG Y, PAN X, HUANG Y, GAO Z, YU H, HAN X (2008) NP-induced biophysical and biochemical alterations of rat testicular Sertoli cell membranes related to disturbed intracellular $\mathrm{Ca}(2+)$ homeostasis. Toxicol Lett 183: 10-20.

GUENTHER K, HEINKE V, THIELE B, KLEIST E, PRAST H, RAECKER T (2002) Endocrine disrupting nonylphenols are ubiquitous in food. Environ Sci Technol 36: 1676-1680.

HAN SW, LEE H, HAN SY, LIM DS, JUNG KK, KWACK SJ, KIM KB, LEE BM (2009) An exposure assessment of di-(2-ethylhexyl) phthalate (DEHP) and di-n-butyl phthalate (DBP) in human semen. J Toxicol Environ Health A 72: 1463-1469. 
HAN X, TU Z, WANG X, SHEN S, HOU Y (2004) Nonylphenol induced apoptosis in rat testis through the Fas/FasL pathway. Bull Environ Contam Toxicol 73: 620-627.

HENKLER F, BEHRLE E, DENNEHY KM, WICOVSKY A, PETERS N, WARNKE C, PFIZENMAIER K, WAJANT H (2005) The extracellular domains of FasL and Fas are sufficient for the formation of supramolecular FasL-Fas clusters of high stability. J Cell Biol 168: 10871098.

HERMO L, PELLETIER RM, CYR DG, SMITH CE (2010) Surfing the wave, cycle, life history, and genes/proteins expressed by testicular germ cells. Part 1: background to spermatogenesis, spermatogonia, and spermatocytes. Microsc Res Tech 73: 241-278

HONARPOUR N, DU C, RICHARDSON JA, HAMMER RE, WANG X, HERZ J (2000) Adult Apaf-1-deficient mice exhibit male infertility. Dev Biol 218: 248-258.

HUANG LP, LEE CC, HSU PC, SHIH TS (2011) The association between semen quality in workers and the concentration of di(2-ethylhexyl) phthalate in polyvinyl chloride pellet plant air. Fertil Steril 96: 90-94.

HUANG PC, KUO PL, CHOU YY, LIN SJ, LEE CC (2009) Association between prenatal exposure to phthalates and the health of newborns. Environ Int 35: 14-20.

HUCKINS C (1978) The morphology and kinetics of spermatogonial degeneration in normal adult rats: an analysis using a simplified classification of the germinal epithelium. Anat Rec 190: 905-926.

HUGHES PJ, MCLELLAN H, LOWES DA, KAHN SZ, BILMEN JG, TOVEY SC, GODFREY RE, MICHELL RH, KIRK CJ, MICHELANGELI F (2000) Estrogenic alkylphenols induce cell death by inhibiting testis endoplasmic reticulum $\mathrm{Ca}(2+)$ pumps. Biochem Biophys Res Commun 277: 568-574.

INOUE K, WADA M, HIGUCHI T, OSHIO S, UMEDA T, YOSHIMURA Y, NAKAZAWA H (2002) Application of liquid chromatography-mass spectrometry to the quantification of bisphenol A in human semen. J Chromatogr B Analyt Technol Biomed Life Sci 773: 97-102.

JAHNUKAINEN K, CHRYSIS D, HOU M, PARVINEN M, EKSBORG S, SODER O (2004) Increased apoptosis occurring during the first wave of spermatogenesis is stage-specific and primarily affects midpachytene spermatocytes in the rat testis. Biol Reprod 70: 290-296.

JENSEN TK, TOPPARI J, KEIDING N, SKAKKEBAEK NE (1995) Do environmental estrogens contribute to the decline in male reproductive health? Clin Chem 41: 1896-1901.

JI G, GU A, HU F, WANG S, LIANG I, XIA Y, LU C, SONG L, FU G, WANG $X$ (2009) Polymorphisms in cell death pathway genes are associated with altered sperm apoptosis and poor semen quality. Hum Reprod 24: 24392446.

KLIP H, VERLOOP J, VAN GOOL JD, KOSTER ME, BURGER CW, VAN LEEUWEN FE (2002) Hypospadias in sons of women exposed to diethylstilbestrol in utero: a cohort study. Lancet 359: 1102-1107.

KNUDSON CM, TUNG KS, TOURTELLOTTE WG, BROWN GA, KORSMEYER SJ (1995) Bax-deficient mice with lymphoid hyperplasia and male germ cell death. Science 270: 96-99.

KOENEN RR, PRUESSMEYER J, SOEHNLEIN O, FRAEMOHS L, ZERNECKE A, SCHWARZ N, REISS K, SARABI A, LINDBOM L, HACKENG TM, WEBER C, LUDWIG A (2009) Regulated release and functional modulation of junctional adhesion molecule A by disintegrin metalloproteinases. Blood 113: 4799-4809.

KU B, LIANG C, JUNG JU, OH BH (2010) Evidence that inhibition of BAX activation by BCL-2 involves its tight and preferential interaction with the BH3 domain of BAX. Cell Res 21: 627-641.

KURIBAYASHI K, MAYES PA, EL-DEIRY WS (2006) What are caspases 3 and 7 doing upstream of the mitochondria? Cancer Biol Ther 5: 763-765.

LAMBROT R, MUCZYNSKI V, LECUREUIL C, ANGENARD G, COFFIGNY H, PAIRAULT C, MOISON D, FRYDMAN R, HABERT R, ROUILLERFABRE V (2009) Phthalates impair germ cell development in the human fetal testis in vitro without change in testosterone production. Environ Health Perspect 117: 32-37.

LEE NP, CHENG CY (2004) Adaptors, junction dynamics, and spermatogenesis. Biol Reprod 71: 392-404.

LI D, ZHOU Z, QING D, HE Y, WU T, MIAO M, WANG J, WENG X, FERBER JR, HERRINTON LJ, ZHU Q, GAO E, CHECKOWAY H, YUAN W (2010) Occupational exposure to bisphenol-A (BPA) and the risk of self-reported male sexual dysfunction. Hum Reprod 25: 519-527.

LI DK, ZHOU Z, MIAO M, HE Y, WANG J, FERBER J, HERRINTON LJ, GAO E, YUAN W (2011a) Urine bisphenol-A (BPA) level in relation to semen quality. Fertil Steril 95: 625-630 e621-624.
LI S, DAI J, ZHANG L, ZHANG J, ZHANG Z, CHEN B (2011b) An association of elevated serum prolactin with phthalate exposure in adult men. Biomed Environ Sci 24: 31-39.

LI YJ, SONG TB, CAI YY, ZHOU JS, SONG X, ZHAO X, WU XL (2009) Bisphenol A exposure induces apoptosis and upregulation of Fas/FasL and caspase-3 expression in the testes of mice. Toxicol Sci 108: 427-436.

LIAO C, KANNAN K (2011) High Levels of Bisphenol A in Paper Currencies from Several Countries, and Implications for Dermal Exposure. Environ Sci Technol.

LIN H, GE RS, CHEN GR, HU GX, DONG L, LIAN QQ, HARDY DO, SOTTAS CM, LI XK, HARDY MP (2008) Involvement of testicular growth factors in fetal Leydig cell aggregation after exposure to phthalate in utero. Proc Natl Acad Sci U S A 105: 7218-7222.

LIN YC, YAO PL, RICHBURG JH (2010) FasL Gene-Deficient Mice Display a Limited Disruption in Spermatogenesis and Inhibition of Mono-(2ethylhexyl) Phthalate-Induced Germ Cell Apoptosis. Toxicol Sci 114 335-345.

LIU WH, CHANG LS (2009) Arachidonic acid induces Fas and FasL upregulation in human leukemia U937 cells via Ca2+/ROS-mediated suppression of ERK/c-Fos pathway and activation of p38 MAPK/ATF-2 pathway. Toxicol Lett 191: 140-148.

LIZAMA C, ALFARO I, REYES JG, MORENO RD (2007) Up-regulation of CD95 (Apo-1/Fas) is associated with spermatocyte apoptosis during the first round of spermatogenesis in the rat. Apoptosis 12: 499-512.

LIZAMA C, LAGOS CF, LAGOS-CABRE R, CANTUARIAS L, RIVERA F, HUENCHUNIR P, PEREZ-ACLE T, CARRION F, MORENO RD (2009) Calpain inhibitors prevent p38 MAPK activation and germ cell apoptosis after heat stress in pubertal rat testes. J Cell Physiol 221: 296305.

LIZAMA C, LUDWIG A, MORENO RD (2011) Etoposide induces apoptosis and upregulation of TACE/ADAM17 and ADAM10 in an in vitro male germ cell line model. Biochim Biophys Acta 1813: 120-128.

LIZAMA C, ROJAS-BENITEZ D, ANTONELLI M, LUDWIG A, BUSTAMANTE-MARIN X, BROUWER-VISSER J, MORENO RD (2010) TACE/ADAM17 is involved in germ cell apoptosis during rat spermatogenesis. Reproduction 140: 305-317.

LIZAMA C, ROJAS-BENITEZ D, ANTONELLI M, LUDWIG A, MORENO RD (2012) Involvement of TACE/ADAM17 and ADAM10 in etoposideinduced apoptosis of germ cells in rat spermatogenesis. J Cell Physiol 227: 829-838.

MAEDA Y, SHIRATSUCHI A, NAMIKI M, NAKANISHI Y (2002) Inhibition of sperm production in mice by annexin $\mathrm{V}$ microinjected into seminiferous tubules: possible etiology of phagocytic clearance of apoptotic spermatogenic cells and male infertility. Cell Death Differ 9: 742-749.

MAIN KM, MORTENSEN GK, KALEVA MM, BOISEN KA, DAMGAARD IN, CHELLAKOOTY M, SCHMIDT IM, SUOMI AM, VIRTANEN HE, PETERSEN DV, ANDERSSON AM, TOPPARI J, SKAKKEBAEK NE (2006) Human breast milk contamination with phthalates and alterations of endogenous reproductive hormones in infants three months of age. Environ Health Perspect 114: 270-276.

MARINO M, GALLUZZO P, ASCENZI P (2006) Estrogen signaling multiple pathways to impact gene transcription. Curr Genomics 7: 497-508.

MCCLUSKY LM, DE JAGER C, BORNMAN MS (2007) Stage-related increase in the proportion of apoptotic germ cells and altered frequencies of stages in the spermatogenic cycle following gestational, lactational, and direct exposure of male rats to p-nonylphenol. Toxicol Sci 95: 249-256.

MEEKER JD, EHRLICH S, TOTH TL, WRIGHT DL, CALAFAT AM, TRISINI AT, YE X, HAUSER R (2010) Semen quality and sperm DNA damage in relation to urinary bisphenol A among men from an infertility clinic. Reprod Toxicol 30: 532-539.

MENDIOLA J, JORGENSEN N, ANDERSSON AM, CALAFAT AM, YE $X$, REDMON JB, DROBNIS EZ, WANG C, SPARKS A, THURSTON SW, LIU F, SWAN SH (2010) Are environmental levels of bisphenol a associated with reproductive function in fertile men? Environ Health Perspect 118: 1286-1291.

MORENO RD, ALVARADO CP (2006) The mammalian acrosome as a secretory lysosome: new and old evidence. Mol Reprod Dev 73: 14301434.

MORENO RD, LIZAMA C, URZUA N, VERGARA SP, REYES JG (2006) Caspase activation throughout the first wave of spermatogenesis in the rat. Cell Tissue Res 325: 533-540.

MORENO RD, URRIOLA-MUÑOZ P, LAGOS-CABRÉ (2011) The emerging role of matrix metalloproteases of the ADAM family in male germ cell apoptosis. Spermatogenesis 1: 195-208. 
MRUK DD, CHENG CY (2004) Sertoli-Sertoli and Sertoli-germ cell interactions and their significance in germ cell movement in the seminiferous epithelium during spermatogenesis. Endocr Rev 25: 747806.

O'DONNELL L, ROBERTSON KM, JONES ME, SIMPSON ER (2001) Estrogen and spermatogenesis. Endocr Rev 22: 289-318.

OAKBERG EF (1956) A description of spermiogenesis in the mouse and its use in analysis of the cycle of the seminiferous epithelium and germ cell renewal. Am J Anat 99: 391-413.

OATLEY JM, BRINSTER RL (2008) Regulation of spermatogonial stem cell self-renewal in mammals. Annu Rev Cell Dev Biol 24: 263-286.

OKADA A, KAI O (2008) Effects of estradiol-17beta and bisphenol A administered chronically to mice throughout pregnancy and lactation on the male pups' reproductive system. Asian J Androl 10: 271-276.

ORTIZ RJ, LIZAMA C, CODELIA VA, MORENO RD (2009) A molecular evaluation of germ cell death induced by etoposide in pubertal rat testes. Mol Hum Reprod 15: 363-371.

PANT N, SHUKLA M, KUMAR PATEL D, SHUKLA Y, MATHUR N, KUMAR GUPTA Y, SAXENA DK (2008) Correlation of phthalate exposures with semen quality. Toxicol Appl Pharmacol 231: 112-116.

PHILLIPS KP, TANPHAICHITR N (2008) Human exposure to endocrine disrupters and semen quality. J Toxicol Environ Health B Crit Rev 11: 188-220.

RICHBURG JH, BOEKELHEIDE K (1996) Mono-(2-ethylhexyl) phthalate rapidly alters both Sertoli cell vimentin filaments and germ cell apoptosis in young rat testes. Toxicol Appl Pharmacol 137: 42-50.

RIEDL SJ, SHI Y (2004) Molecular mechanisms of caspase regulation during apoptosis. Nat Rev Mol Cell Biol 5: 897-907.

RODRIGUEZ I, ODY C, ARAKI K, GARCIA I, VASSALLI P (1997) An early and massive wave of germinal cell apoptosis is required for the development of functional spermatogenesis. Embo J 16: 2262-2270.

ROUTLEDGE EJ, WHITE R, PARKER MG, SUMPTER JP (2000) Differential effects of xenoestrogens on coactivator recruitment by estrogen receptor (ER) alpha and ERbeta. J Biol Chem 275: 35986-35993.

ROY JR, CHAKRABORTY S, CHAKRABORTY TR (2009) Estrogen-like endocrine disrupting chemicals affecting puberty in humans--a review. Med Sci Monit 15: RA137-145.

ROZATI R, REDDY PP, REDDANNA P, MUJTABA R (2002) Role of environmental estrogens in the deterioration of male factor fertility. Fertil Steril 78: 1187-1194.

RUSSELL LB (2004) Effects of male germ-cell stage on the frequency, nature, and spectrum of induced specific-locus mutations in the mouse. Genetica 122: 25-36.

RUSSELL LD, CHIARINI-GARCIA H, KORSMEYER SJ, KNUDSON CM (2002) Bax-dependent spermatogonia apoptosis is required for testicular development and spermatogenesis. Biol Reprod 66: 950-958.

RUWANPURA S, MCLACHLAN R, MEACHEM S (2010) Hormonal regulation of germ cell development. J Endocrinol 205: 117-131.

SALAZAR G, JOSHI A, LIU D, WEI H, PERSSON JL, WOLGEMUTH DJ (2005) Induction of apoptosis involving multiple pathways is a primary response to cyclin A1-deficiency in male meiosis. Dev Dyn 234: 114-123.

SALAZAR G, LIU D, LIAO C, BATKIEWICZ L, ARBING R, CHUNG SS, LELE K, WOLGEMUTH DJ (2003) Apoptosis in male germ cells in response to cyclin A1-deficiency and cell cycle arrest. Biochem Pharmacol 66: 1571-1579.

SALIAN S, DOSHI T, VANAGE G (2009) Neonatal exposure of male rats to Bisphenol A impairs fertility and expression of sertoli cell junctional proteins in the testis. Toxicology 265: 56-67.

SALVESEN GS (2002) Caspases: opening the boxes and interpreting the arrows. Cell Death Differ 9: 3-5.

SATO T, MACHIDA T, TAKAHASHI S, IYAMA S, SATO Y, KURIBAYASHI $\mathrm{K}$, TAKADA K, OKU T, KAWANO Y, OKAMOTO T, TAKIMOTO R, MATSUNAGA T, TAKAYAMA T, TAKAHASHI M, KATO J, NIITSU $Y$ (2004) Fas-mediated apoptosome formation is dependent on reactive oxygen species derived from mitochondrial permeability transition in Jurkat cells. J Immunol 173: 285-296.

SCAFFIDI C, FULDA S, SRINIVASAN A, FRIESEN C, LI F, TOMASELLI KJ, DEBATIN KM, KRAMMER PH, PETER ME (1998) Two CD95 (APO-1/ Fas) signaling pathways. Embo J 17: 1675-1687.

SCAFFIDI C, SCHMITZ I, ZHA J, KORSMEYER SJ, KRAMMER PH, PETER ME (1999) Differential modulation of apoptosis sensitivity in CD95 type I and type II cells. J Biol Chem 274: 22532-22538.

SCHLONDORFF J, BLOBEL CP (1999) Metalloprotease-disintegrins: modular proteins capable of promoting cell-cell interactions and triggering signals by protein-ectodomain shedding. J Cell Sci 112: 36033617
SHARPE RM, MCKINNELL C, KIVLIN C, FISHER JS (2003) Proliferation and functional maturation of Sertoli cells, and their relevance to disorders of testis function in adulthood. Reproduction 125: 769-784.

SHETTY J, MARATHE GK, DIGHE RR (1996) Specific immunoneutralization of FSH leads to apoptotic cell death of the pachytene spermatocytes and spermatogonial cells in the rat. Endocrinology 137: 2179-2182.

SHI Y (2002) Apoptosome: the cellular engine for the activation of caspase-9. Structure 10: 285-288.

SHI Y (2006) Mechanical aspects of apoptosome assembly. Curr Opin Cell Biol 18: 677-684.

SILVA D, LIZAMA C, TAPIA V, R.D. M (2011) Propylthiouracilinduced hypothyroidism delays apoptosis during the first wave of spermatogenesis. Biol Res 44: 181-188.

SKINNER MK (2005). Sertoli cell secreted regulatori factors. Sertoli cell Biology. M. K. a. G. Skinner, M.D. New York, Elsevier: 107-121.

SOBARZO CM, LUSTIG L, PONZIO R, SUESCUN MO, DENDUCHIS B (2009) Effects of di(2-ethylhexyl) phthalate on gap and tight junction protein expression in the testis of prepubertal rats. Microsc Res Tech 72: 868-877.

SWAN SH, MAIN KM, LIU F, STEWART SL, KRUSE RL, CALAFAT AM, MAO CS, REDMON JB, TERNAND CL, SULLIVAN S, TEAGUE JL (2005) Decrease in anogenital distance among male infants with prenatal phthalate exposure. Environ Health Perspect 113: 1056-1061.

TAKAO T, NANAMIYA W, NAZARLOO HP, MATSUMOTO R, ASABA K, HASHIMOTO K (2003) Exposure to the environmental estrogen bisphenol A differentially modulated estrogen receptor-alpha and -beta immunoreactivity and mRNA in male mouse testis. Life Sci 72: 11591169.

TER VELD MG, SCHOUTEN B, LOUISSE J, VAN ES DS, VAN DER SAAG PT, RIETJENS IM, MURK AJ (2006) Estrogenic potency of foodpackaging-associated plasticizers and antioxidants as detected in ERalpha and ERbeta reporter gene cell lines. J Agric Food Chem 54: 4407-4416.

TESARIK J, MARTINEZ F, RIENZI L, IACOBELLI M, UBALDI F, MENDOZA C, GRECO E (2002) In-vitro effects of FSH and testosterone withdrawal on caspase activation and DNA fragmentation in different cell types of human seminiferous epithelium. Hum Reprod 17: 18111819.

TOPPARI J, LARSEN JC, CHRISTIANSEN P, GIWERCMAN A, GRANDJEAN P, GUILLETTE LJ, JR., JEGOU B, JENSEN TK, JOUANNET P, KEIDING N, LEFFERS H, MCLACHLAN JA, MEYER O, MULLER J, RAJPERT-DE MEYTS E, SCHEIKE T, SHARPE R, SUMPTER J, SKAKKEBAEK NE (1996) Male reproductive health and environmental xenoestrogens. Environ Health Perspect 104 Suppl 4: 741-803.

TOYAMA Y, SUZUKI-TOYOTA F, MAEKAWA M, ITO C, TOSHIMORI K (2004) Adverse effects of bisphenol A to spermiogenesis in mice and rats. Arch Histol Cytol 67: 373-381.

TRIPATHI R, MISHRA DP, SHAHA C (2009) Male germ cell development: turning on the apoptotic pathways. J Reprod Immunol 83: 31-35.

VILLUNGER A, MICHALAK EM, COULTAS L, MULLAUER F, BOCK G, AUSSERLECHNER MJ, ADAMS JM, STRASSER A (2003) p53- and drug-induced apoptotic responses mediated by BH3-only proteins puma and noxa. Science 302: 1036-1038.

WANG RS, YEH S, TZENG CR, CHANG C (2009) Androgen receptor roles in spermatogenesis and fertility: lessons from testicular cell-specific androgen receptor knockout mice. Endocr Rev 30: 119-132.

WEIKERT S, SCHRADER M, MULLER M, KRAUSE H, MILLER K (2004) Expression of the apoptosis inhibitor survivin in testicular tissue of infertile patients. Int J Androl 27: 161-165.

WESTPHAL D, DEWSON G, CZABOTAR PE, KLUCK RM (2010) Molecular biology of Bax and Bak activation and action. Biochim Biophys Acta 1813: 521-531.

WHITE JM (2003) ADAMs: modulators of cell-cell and cell-matrix interactions. Curr Opin Cell Biol 15: 598-606.

WHO (2010). Examination and processing of human semen. Switzerland, World Health Organization.

WONG CH, XIA W, LEE NP, MRUK DD, LEE WM, CHENG CY (2005) Regulation of ectoplasmic specialization dynamics in the seminiferous epithelium by focal adhesion-associated proteins in testosteronesuppressed rat testes. Endocrinology 146: 1192-1204.

YAMAMOTO CM, HIKIM AP, LUE Y, PORTUGAL AM, GUO TB, HSU SY, SALAMEH WA, WANG C, HSUEH AJ, SWERDLOFF RS (2001) Impairment of spermatogenesis in transgenic mice with selective overexpression of Bcl-2 in the somatic cells of the testis. J Androl 22: 981-991. 
YAN HH, MRUK DD, CHENG CY (2008) Junction restructuring and spermatogenesis: the biology, regulation, and implication in male contraceptive development. Curr Top Dev Biol 80: 57-92.

YAN W, HUANG JX, LAX AS, PELLINIEMI L, SALMINEN E, POUTANEN M, TOPPARI J (2003) Overexpression of Bcl-W in the testis disrupts spermatogenesis: revelation of a role of BCL-W in male germ cell cycle control. Mol Endocrinol 17: 1868-1879.

YAN W, SUOMINEN J, SAMSON M, JEGOU B, TOPPARI J (2000a) Involvement of $\mathrm{Bcl}-2$ family proteins in germ cell apoptosis during testicular development in the rat and pro-survival effect of stem cell factor on germ cells in vitro. Mol Cell Endocrinol 165: 115-129.

YAN W, SUOMINEN J, TOPPARI J (2000b) Stem cell factor protects germ cells from apoptosis in vitro. J Cell Sci 113 ( Pt 1): 161-168.

YAO PL, LIN YC, RICHBURG JH (2009) Mono-(2-Ethylhexyl) PhthalateInduced Disruption of Junctional Complexes in the Seminiferous Epithelium of the Rodent Testis Is Mediated by MMP2. Biol Reprod.

YAO PL, LIN YC, RICHBURG JH (2010) Mono-(2-Ethylhexyl) PhthalateInduced Disruption of Junctional Complexes in the Seminiferous
Epithelium of the Rodent Testis Is Mediated by MMP2. Biol Reprod 82 516-527.

YAO PL, LIN YC, SAWHNEY P, RICHBURG JH (2007) Transcriptional regulation of FasL expression and participation of sTNF-alpha in response to sertoli cell injury. J Biol Chem 282: 5420-5431.

YIN Y, STAHL BC, DEWOLF WC, MORGENTALER A (1998) p53-mediated germ cell quality control in spermatogenesis. Dev Biol 204: 165-171.

YOULE RJ, STRASSER A (2008) The BCL-2 protein family: opposing activities that mediate cell death. Nat Rev Mol Cell Biol 9: 47-59.

YOUNG KW, PINON LG, DHIRAJ D, TWIDDY D, MACFARLANE M, HICKMAN J, NICOTERA P (2010) Mitochondrial fragmentation and neuronal cell death in response to the $\mathrm{Bcl}-2 / \mathrm{Bcl}-\mathrm{x}(\mathrm{L}) / \mathrm{Bcl}-\mathrm{w}$ antagonist ABT-737. Neuropharmacology 58: 1258-1267.

ZHAI D, JIN C, HUANG Z, SATTERTHWAIT AC, REED JC (2008) Differential regulation of Bax and Bak by anti-apoptotic Bcl-2 family proteins Bcl-B and Mcl-1. J Biol Chem 283: 9580-9586.

ZHANG Y, LIN L, CAO Y, CHEN B, ZHENG L, GE RS (2009) Phthalate levels and low birth weight: a nested case-control study of Chinese newborns. J Pediatr 155: 500-504 